\title{
The Heats of Mixing of Poly(guanylic acid) and Poly(cytidylic acid)
}

\author{
Yoshihiro Baba, Kazuhiko Fujioka, and Akihiro Kagemoto \\ Department of General Education, Osaka Institute of \\ Technology, Asahi-ku, Osaka 535, Japan.
}

(Received June 20, 1977)

\begin{abstract}
The heats of mixing of an equimolar mixture of poly $G$ and poly $C$ in solutions of various $\mathrm{pH}$ values were measured using a LKB batch type of microcalorimeter at $298 \pm 0.002 \mathrm{~K}$. The interaction between poly $\mathrm{G}$ and poly $\mathrm{C}$ in neutral medium seems to lead to a complex such as poly $(G+C)$. In order to obtain further information about the interaction between poly $G$ and poly $C$, the $C D$ spectra for poly $\mathrm{G}$, poly $\mathrm{C}$, and an equimolar mixture of poly $\mathrm{G}$ and poly $\mathrm{C}$ in solutions with various $\mathrm{pH}$ were also measured. From the results of the heats of mixing and the spectra measurements, it was concluded that poly $\mathrm{G}$ and poly $\mathrm{C}$ in neutral medium leads to a weak complex formation and the enthalpy of complex formation was stoichiometrically estimated to be about $-9.3 \mathrm{~kJ}$ per mol of base pair.

KEY WORDS Heats of Mixing / CD Spectrum / Poly G / Poly

C / Weak Interaction of Poly G and Poly C /
\end{abstract}

In a previous paper, ${ }^{1}$ we measured the heats of mixing of an equimolar mixture of poly $\mathrm{A}$ and poly $U$ using a twin microcalorimeter at $298 \mathrm{~K}$, and reported that an equimolar mixture of poly $A$ and poly $U$ forms the poly $(A+U)$ complex between different chains and also the stability of this structure depends on the concentration of salt; also, the enthalpy of complex formation is estimated to be approximately about $-15.5 \mathrm{~kJ}$ at $\mathrm{pH} 7.60$.

In addition, the poly(guanylic acid) (poly G)poly(citidylic acid) (poly C) base pair is generally the most commom base pair as well as that of poly $\mathrm{A}$ and poly $\mathrm{U}$ found in DNA molecule.

The spectrophotometric studies on the interaction between poly $\mathrm{G}$ and poly $\mathrm{C}$ have been reported by many investigators. ${ }^{2-5}$ In 1971, Thiele, et al., ${ }^{2}$ reported that an equimolar mixture of poly $\mathrm{G}$ and poly $\mathrm{C}$ forms the $\operatorname{poly}(\mathrm{G}+\mathrm{C})$ complex in acid solution ( $\mathrm{pH} \mathrm{2-4)}$ from the measurement of the optical method.

In this paper, in order to obtain further information about the stability of the DNA structure, the heats of mixing of an equimolar mixture of poly $\mathrm{G}$ and poly $\mathrm{C}$ were measured using a LKB microcalorimeter at $298 \pm 0.002 \mathrm{~K}$.

\section{EXPERIMENTAL}

\section{Apparatus}

The calorimeter used in this study was the LKB batch type of the microcalorimeter; it was placed in an air bath kept at $298 \pm 0.002 \mathrm{~K}$. The air bath was designed as follows. Around the outside surface of the air bath, a copper pipe $(10 \mathrm{~mm}$ diameter) was wound and the water maintained at $298 \pm 0.01 \mathrm{~K}$ in the water bath was circulated around the outside surface of chamber through the copper pipe using a thermoelectric apparatus (Model DE 18 Sharp Electronic Co. Ltd., Japan). The temperature change in the air bath was detected by a thermister which has $34.0 \mathrm{k} \Omega$ at $298 \mathrm{~K}$.

The circular dichroism of the poly $\mathrm{G}$, poly $\mathrm{C}$, and an equimolar mixture of poly $G$ and poly C solutions were measured by a spectropolarimeter (Japan Spectroscopic Co. Ltd., J-20).

\section{Materials}

Poly $\mathrm{G}$ and poly $\mathrm{C}$ samples were purchased from Miles Co. Ltd. All other materials were 
commercial preparations of analytical reagent grade. The buffer solution used to adjust $\mathrm{pH}$ in this study was $0.01-\mathrm{mol} / l$ tris- $\mathrm{HCl}$ buffer* solution ( $\mathrm{pH} 7.60$ ) and the Mcllvaine buffer** solution ( $\mathrm{pH} 3.00-8.00)$.

\section{RESULTS AND DISCUSSION}

\section{The Heats of Mixing of Poly $G$ and Poly $C$}

The heats of mixing of an equimolar mixture of poly $\mathrm{G}$ and poly $\mathrm{C}$ in the solutions with various $\mathrm{pH}$ were measured. The results obtained are shown in Figure 1, showing the heats of mixing per mol of base pair, $\Delta H^{\mathrm{M}}$, plotted against $\mathrm{pH}$.

As seen in Figure $1, \Delta H^{\mathrm{M}}$ in the Mcllvaine buffer solution without $\mathrm{NaCl}$ is zero. In the case of buffer solution containing $0.01-\mathrm{mol} / \mathrm{l}$ $\mathrm{NaCl}, \Delta H^{\mathrm{M}}$ is zero in the $\mathrm{pH}$ ranges from 3 to 4 , and proves to be exothermic when the $\mathrm{pH}$ is higher than 4 , and reaches a definite value of $-3.9 \mathrm{~kJ}$ which is nearly independent of $\mathrm{pH}$ when $\mathrm{pH}$ is higher than 5; this indicates that the interaction between poly $\mathrm{G}$ and poly $\mathrm{C}$ in neutral medium exists.

Assuming that the interaction between poly $G$ and poly $\mathrm{C}$ in neutral medium may form the poly $(\mathrm{G}+\mathrm{C})$ complex, the heats of the mixing of an eqimolar mixture of poly $G$ and poly $C$ were measured over a concentration range from

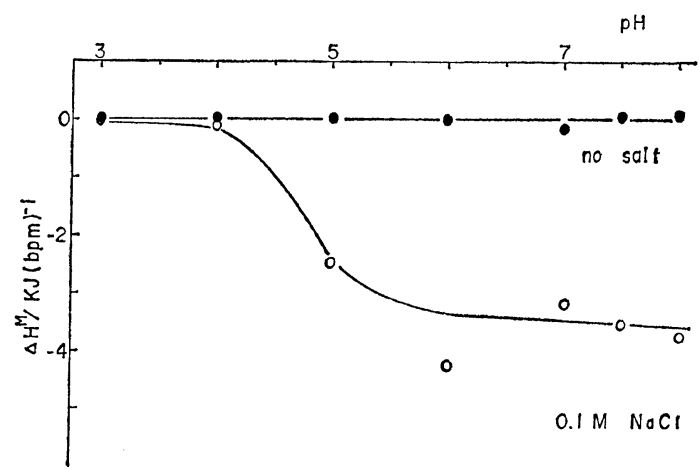

Figure 1. The heats of mixing of an equimolar mixture of poly $\mathrm{G}$ and poly $\mathrm{C}$ in solutions with $0.1-\mathrm{mol} / l \mathrm{NaCl}(\bigcirc)$, and without $\mathrm{NaCl}(\mathrm{O})$ at various $\mathrm{pH}$.

* Tris(hydroxymetyl)aminomethane-hydrochloric acid.

** Mixture of $0.02-\mathrm{mol} / l$ disodium hydrogenphosphate and $0.01-\mathrm{mol} / l$ citric acid.

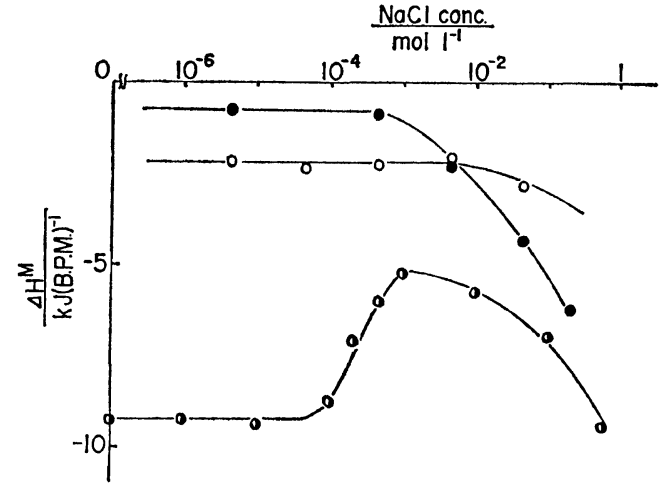

Figure 2. The heats of mixing of an equimolar mixture of poly $\mathrm{G}$ and poly $\mathrm{C}(\mathbf{C})$, poly $\mathrm{G}-\mathrm{NaCl}$ $(O)$, and poly $\mathrm{C}-\mathrm{NaCl}(\bigcirc)$ systems at $\mathrm{pH} 7.60$ (tris- $\mathrm{HCl}$ buffer solution).

0 to $0.5-\mathrm{mol} / l \mathrm{NaCl}$ solution, using the same calorimeter at $298 \pm 0.002 \mathrm{~K}$.

This system proved to be exothermic, and the results obtained are shown in Figure 2, in which the heats of mixing per mol of base pair, $\Delta H^{\mathrm{M}}$, are plotted against the concentration of $\mathrm{NaCl}$.

As seen in Figure $2, \Delta H^{\mathrm{M}}$ has a definite value of $-9.3 \mathrm{~kJ}$ at $\mathrm{NaCl}$ concentration below $10^{-4}$ molar. However, $\Delta H^{\mathrm{M}}$ shows a drastic decrease in the $10^{-4}$ to $10^{-3}$ molar concentration region of $\mathrm{NaCl}$, and again increases with an increasing concentration of $\mathrm{NaCl}$.

To obtain more information about the interesting behavior of $\Delta H^{\mathrm{M}}$, the heats of mixing of poly $\mathrm{G}-$ and poly $\mathrm{C}-\mathrm{NaCl}$ systems at various concentrations of $\mathrm{NaCl}$ under the same experimental conditions, as in an equimolar mixture of poly $\mathrm{G}$ and poly $\mathrm{C}$, were also measured, and the results obtained are included in Figure 2. As seen in Figure 2, the heats of mixing of poly $\mathrm{C}$ and $\mathrm{NaCl}$ solutions have a definite value of $-2.3 \mathrm{~kJ}$ which is nearly independent of the concentration of $\mathrm{NaCl}$. On the other hand, the heats of mixing of poly $\mathrm{G}$ and $\mathrm{NaCl}$ solutions have a definite value of $-0.8 \mathrm{~kJ}$ when the concentration of $\mathrm{NaCl}$ is $10^{-6}$ to $10^{-3}$ molar, but there is a great increase when the concentration of $\mathrm{NaCl}$ is higher than $10^{-3}$ molar. This great increase of $\Delta H^{\mathrm{M}}$ may arise from the fact that the poly $G$ plays an important role for the interaction of an equimolar mixture of poly $G$ and poly $\mathrm{C}$ in salt solution. 
The Heats of Mixing of Poly G and Poly C

CD Spectra for Poly $G$, Poly $C$, and $\operatorname{Poly}(G+C)$ In order to obtain further information about the interaction between poly $G$ and poly $C$ in neutral medium, the $C D$ spectra for poly $G$, poly $C$ and an equimolar mixture of poly $G$
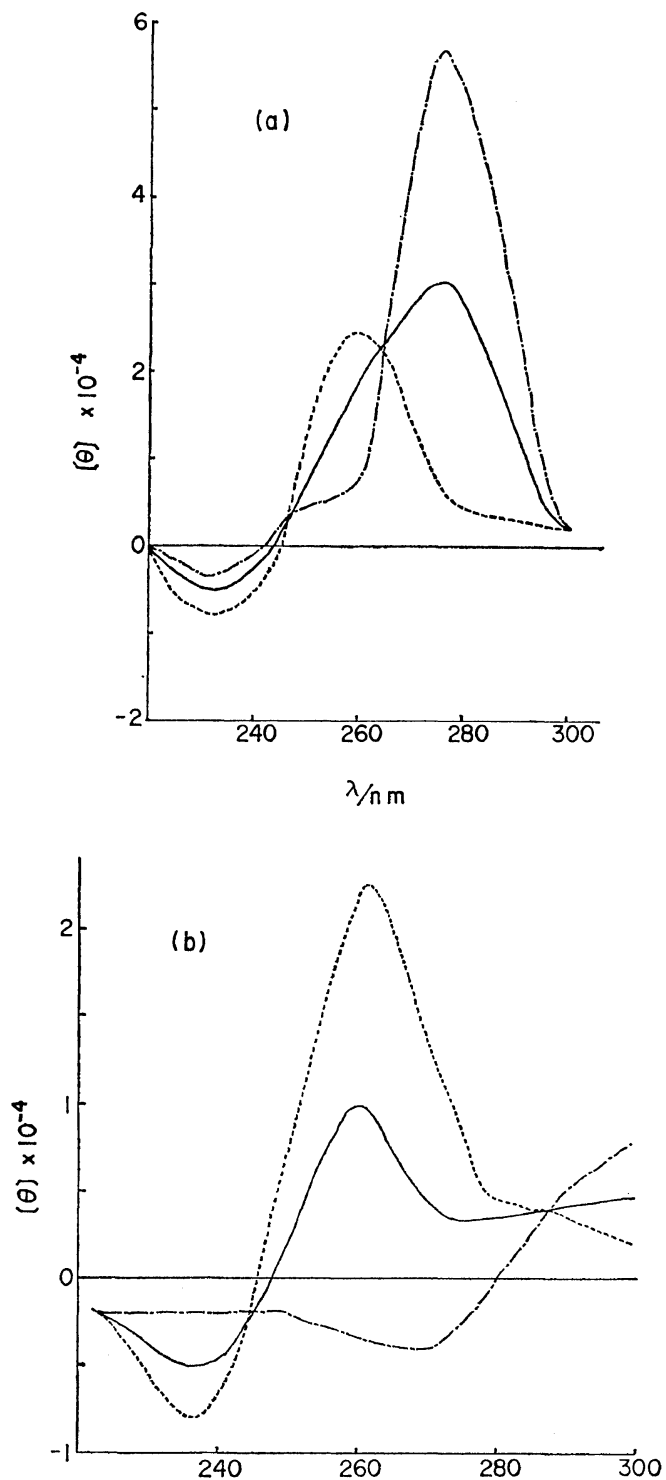

Figure 3. CD spectra of poly $\mathrm{G}(---)$, poly $\mathrm{C}$ (--), and an equimolar mixture of poly $G$ and poly $C$ which is equal to the sum of the CD spectra of poly $\mathbf{G}$ and poly $\mathrm{C}(-)$ under various experimental conditions: (a) $0-\mathrm{mol} / l \mathrm{NaCl}$ at $\mathrm{pH} 6.50$ (Mcllvaine buffer solution); (b) $0.1-\mathrm{mol} / l \mathrm{NaCl}$ at pH 3.00 (Mcllvaine buffer solution).
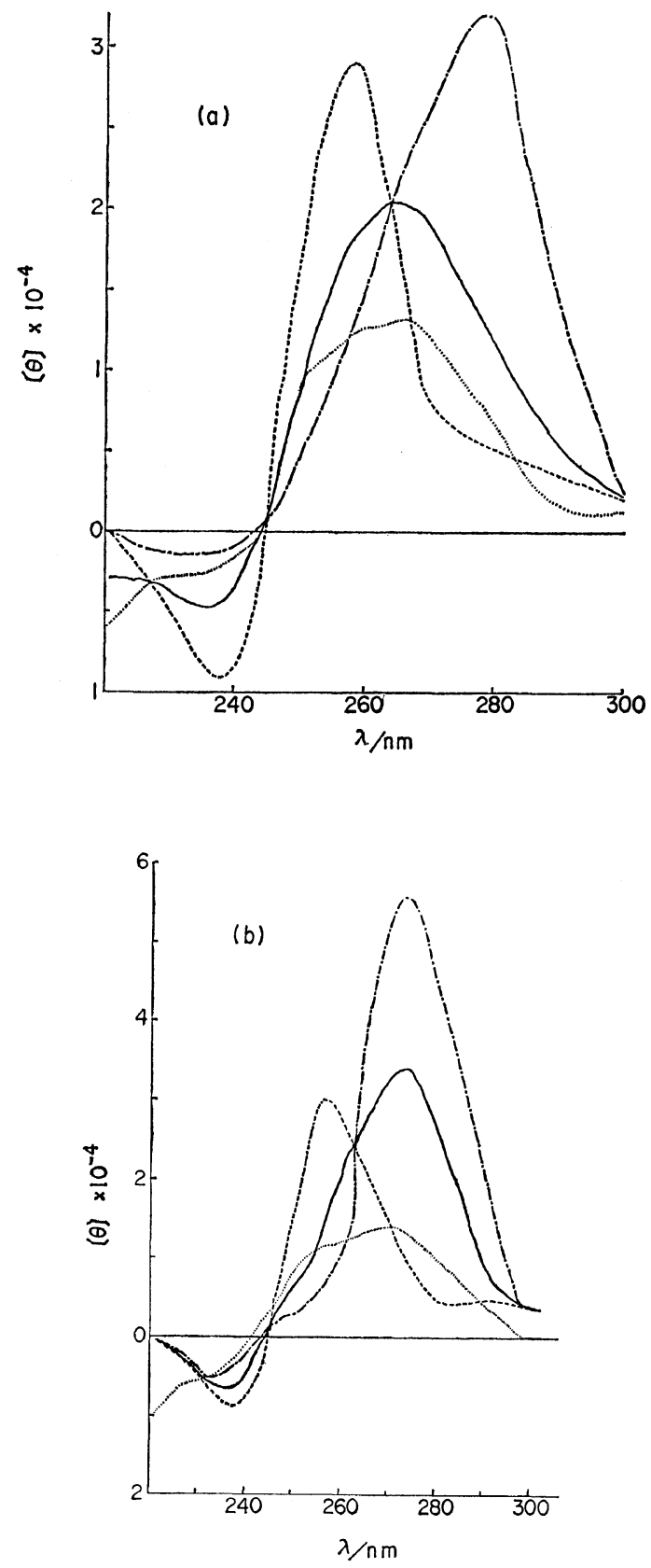

Figure 4. $\mathrm{CD}$ spectra of poly $\mathrm{G}$ (---), poly $\mathrm{C}$ $(--)$, an equimolar mixture of poly $\mathbf{G}$ and poly $C(\cdots)$, and $(-)$ is the sum of the CD spectra of poly $\mathbf{G}$ and poly $\mathrm{C}$ under various experimental conditions: (a) $0.1-\mathrm{mol} / l \mathrm{NaCl}$ at $\mathrm{pH} 5.00$ (Mcllvaine buffer solution); (b) $0.1-\mathrm{mol} / l \mathrm{NaCl}$ at $\mathrm{pH}$ 6.50 (Mcllvaine buffer solution); (c) $10^{-4}-\mathrm{mol} / l$ $\mathrm{NaCl}$ at $\mathrm{pH} 7.60$ (tris- $\mathrm{HCl}$ buffer solution). 


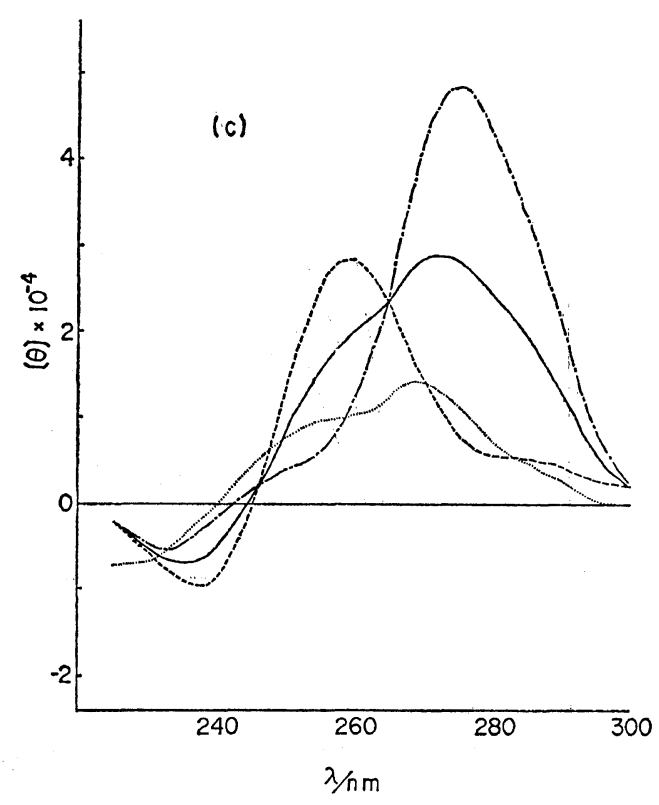

and poly $\mathrm{C}$ solutions with various concentrations of $\mathrm{NaCl}$ were measured and the results obtained are shown in Figure 3(a), (b), and 4(a), (b), (c), respectively.

As seen in Figure 3(a), (b), the CD spectra for an equimolar mixture of poly $\mathrm{G}$ and poly $\mathrm{C}$ in solution without $\mathrm{NaCl}$ at $\mathrm{pH} 6.50$ and in $0.1-\mathrm{mol} / l \mathrm{NaCl}$ solution at $\mathrm{pH} 3.00$ are consistent with those obtained by adding the $C D$ spectrum of poly $G$ and poly $C$, suggesting that poly $\mathbf{G}$ and poly $\mathbf{C}$ may not lead to a complex formation under these experimental conditions. On the other hand, those in the Mcllvaine buffer solution with $0.1-\mathrm{mol} / l \mathrm{NaCl}$ at $\mathrm{pH} 5.00$ and 6.50 and in the tris- $\mathrm{HCl}$ buffer solution with $10^{-4}-\mathrm{mol} / \mathrm{l} \mathrm{NaCl}$ at $\mathrm{pH} 7.60$ differ from the spectra obtained by adding the $C D$ spectrum of poly $G$ and poly $C$ as shown in Figure 4(a), (b), (c).

Thus, the intensity of the positive maximum for an equimolar mixture of poly $G$ and poly $C$ is weaker than that obtained by adding the $C D$ spectrum of poly $G$ and poly $C$, and this decrease of positive maximum corresponds to the formation of a double stranded helical structure of $\operatorname{poly}(\mathrm{A}+\mathrm{U})$ from an equimolar mixture of poly $A$ and poly $U,^{6,7}$ suggesting that poly $G$ and poly $C$ leads to a complex formation between their bases in the Mcllvaine buffer solutions with $0.1-\mathrm{mol} / l \mathrm{NaCl}$ at $\mathrm{pH} 5.00$ and 6.50 and in the tris- $\mathrm{HCl}$ buffer solution with $10^{-4}-\mathrm{mol} / l \mathrm{NaCl}$ at $\mathrm{pH} 7.60$. The interaction at $\mathrm{pH} 5.00,6.50$, and 7.60 may lead to a weak complex from the results of $\mathrm{CD}$ spectra measurements.

The Enthalpy of Interaction of $\operatorname{Poly}(\boldsymbol{G}+\boldsymbol{C})$ Complex

It is difficult to analyze the behavior of $\Delta H^{\mathrm{M}}$ of an equimolar mixture of poly $\mathrm{G}$ and poly $\mathrm{C}$ in a salt solution. But these results may be interpreted as follows.

The mixing process of poly $\mathrm{G}$ and poly $\mathrm{C}$ in a salt solution such as,

$$
\begin{aligned}
& \text { Poly } \mathrm{G} \mathrm{Na} \mathrm{Na}^{+} \text {soln }+ \text { Poly } \mathrm{C} \mathrm{Na} \mathrm{Na}^{+} \text {soln } \\
& \stackrel{\Delta H^{\mathrm{M}}}{\longrightarrow} \operatorname{Poly}(\mathrm{G}+\mathrm{C}) \mathrm{Na}^{+} \text {soln }
\end{aligned}
$$

may be divided into four hypothetical processes as follows.

$$
\begin{aligned}
& \text { Poly G soln }+ \text { Poly C soln } \\
& \stackrel{\Delta H_{1}}{\longrightarrow} \text { Poly }(\mathrm{G}+\mathrm{C}) \text { soln } \\
& \text { Poly }(\mathrm{G}+\mathrm{C}) \text { soln }+\mathrm{Na}^{+} \text {soln } \\
& \stackrel{\Delta H_{2}}{\mathrm{Poly}(\mathrm{G}+\mathrm{C}) \mathrm{Na}^{+} \text {soln }} \\
& \text { Poly } \mathrm{G} \text { soln }+\mathrm{Na}^{+} \text {soln } \\
& \stackrel{\Delta H_{3}}{\longrightarrow} \text { Poly } \mathrm{G} \mathrm{Na}^{+} \text {soln } \\
& \text { Poly C soln }+\mathrm{Na}^{+} \text {soln } \\
& \stackrel{\Delta H_{4}}{\longrightarrow} \text { Poly } \mathrm{C} \mathrm{Na} \mathrm{Na}^{+} \text {soln }
\end{aligned}
$$

Assuming that the heats of dilution in these processes may be negligibly small, the heats of mixing, $\Delta H^{\mathrm{M}}$, will be written as a combination of the heats in the processes mentioned above as follows.

$$
\Delta H^{\mathrm{M}}=\Delta H_{1}+\Delta H_{2}-\left(\Delta H_{3}+\Delta H_{4}\right)
$$

Therefore, the net enthalpy change to form the complex, $\Delta H_{1}$, may be estimated as $\Delta H^{\mathrm{M}}$ $\Delta H_{2}+\left(\Delta H_{3}+\Delta H_{4}\right)$. The values of $\Delta H^{\mathrm{M}}, \Delta H_{3}$, and $\Delta H_{4}$ are measured, but the estimation of $\Delta \mathrm{H}_{2}$ is very difficult. It may be considered that there are the following two approaches for determining the value of $\Delta \mathrm{H}_{2}$.

First, the simplest assumption that $\Delta H_{2}$ may be equal to $\Delta H_{3}+\Delta H_{4}$, will give $\Delta H_{1}$, which is equal to $\Delta H^{\mathrm{M}}$ with $-9.3 \mathrm{~kJ}$. Second, if $\Delta H_{2}$ is lower than $\Delta H_{3}+\Delta H_{4}, \Delta H_{1}$ will be lower than $\Delta H^{\mathrm{M}}$, and vice versa. 
The complex formation heat of $-9.3 \mathrm{~kJ}$ seems small in comparison with that of the poly $(\mathrm{A}+\mathrm{U})$ complex, indicating that a weak complex is formed between poly $\mathrm{G}$ and poly $\mathrm{C}$ in a neutral medium. But an exact determination of $\Delta H_{2}$ will give the exact value of the net enthalpy, $\Delta H_{1}$.

\section{REFERENCES}

1. S. Tanaka, Y. Baba, and A. Kagemoto, Polym. J., 8, 325 (1976).
2. D. Thiele and W.G. Bauer, Biopolymers, 10, 143 (1971).

3. F. Pochon and A. M. Michelson, Biochemistry, 53, 1425 (1965).

4. M. N. Lipsett, J. Biol. Chem., 239, 4, 1256 (1964).

5. A. M. Michelson and F. Pochon, Biochem. Biophys. Acta, 174, 604 (1969).

6. J. Brahms, J. Mol. Biol., 11, 785 (1965).

7. K. Imahori and K. Watanabe, J. Polym. Sci., Part C, No. 30, 633 (1970). 